\title{
INHERITANCE PATTERN OF VOCATIONAL SKILLS: AN ETHNOGRAPHIC STUDY ON CONSTRUCTION WORKERS IN INDONESIA
}

\author{
Lilis Widaningsih ${ }^{1}$, MS Barliana ${ }^{2}$, Tutin Aryanti ${ }^{3}$, \& Elly Malihah ${ }^{4}$ \\ ${ }^{1,2,3}$ Faculty of Technology and Vocational Skills Education \\ Universitas Pendidikan Indonesia \\ Indonesia \\ ${ }^{4}$ Faculty of Social Science Education \\ Universitas Pendidikan Indonesia \\ Indonesia
}

Correspondence author email: $\underline{\text { liswida@upi.edu }}$

Received $5^{\text {th }}$ March 2018; Accepted 29 $9^{\text {th }}$ August 2018

\begin{abstract}
Construction workers in Indonesia have unique characteristics. They earn their vocational skills through cultural inheritance. Construction workers in many construction projects in urban areas mostly come from villages in Java. They learn their vocational skills from their relatives and local communities in their villages. This paper aims at describing how vocational skills are passed down through generations. This qualitative ethnographic and ethnoandragogic study explores the training process, beginning with the recruitment pattern, the network development, skills acquisition and transmission pattern, responses to technology, and attitudes to challenges in modern industry. Through observation and in-depth interview, it was revealed that traditionally the training pattern applied andragogic model principles; i.e., learning by doing and learning on the job. This study provides a base for further research and the development and improvement of vocational education and training model in response to the particular characteristics of construction workers in Indonesia.
\end{abstract}

Keywords: Inheritance pattern; vocational skills; construction workers; ethnography

DOI: https://10.30880/jtet.2018.10.02.007

Vol. 10, No. 2 | December 2018| ISSN 2229-8932 Journal of Technical Education and Training (JTET)| 71 


\section{INTRODUCTION}

Indonesia is one of the largest construction services markets with a value of 267 billion USD. In Asia, Indonesia ranks fourth after China (1.78 trillion USD), Japan (742 billion USD), and India (427 billion USD) (Kementrian Pekerjaan Umum dan Perumahan Rakyat, 2015). The data is supported by the increasing trend of development of construction workers year in year out. At least, the latest data (BPS, 2014) on labor market in construction sector in 2013 was recorded to reach 6.349 .387 persons (6.35\%) and grew significantly in 2014 by 7,280,086 (6.35\%). It means that there is an increase in the involvement of construction workers in the construction industry within one year by $0.70 \%$ or approximately 930,000 workers.

The construction worker in question refers to the executor of the construction of buildings (architecture), which is called a tukang (skilled worker) as arranged in Law No. 13 of 2003 on employment, Law No. 2 of 2017 on construction services, and ministerial regulations and regulation of the Construction Services Development Agency (LPJK). They are average people working in the sun and building material dust in a heavy industry that requires considerable energy (Eaves, Gyi, \& Gibb, 2016). They are the lowest construction workforce working directly with technical works in the field (Haryadi, 2010). They may not receive public attention, but it is their rough hands that do all construction jobs, from simple houses to luxurious buildings, malls, hotels, city parks, and other buildings in urban areas. They come from different parts of the village in groups with their fellow, relatives or friends, carrying carpentry equipment and some supplies to survive in the city.

They earn their construction skills not through formal education and training. Some of them even never went to schools. They mostly are high school graduates, but not many of them are from vocational schools specializing in construction. Of the 7,280,086 construction workers, only $4 \%$ are experts, $20 \%$ are skilled workers, and the remaining $76 \%$ are unskilled laborers (Badan Pusat Statistik, 2014). Therefore, it is not surprising that normally they are not registered as workforce in protected formal sectors (Rothenberg et al., 2016).

They learn construction skills on the job gradually. The career level in the construction jobs are hierarchical like in other sectors, from kenék/ladén (construction laborers) to specialized and skilled workers like bricklayers, carpenters, and painters (Badaruddin, 2015). This skill specialization is established in the work place using their self-developed training models (Widaningsih, 2016; Amir, Martini, \& Luthfiah, 2013).

These established characteristics illustrate a traditional cultural pattern in which these construction workers are born and raised. This study identifies a community's cultural and social dimension that is worthy of attention as an andragogic and lifetime educational issue. The survival of the people will have something to do with how they develop life skills in everyday life to address the global challenges (Sălcudean, Vereş, \& Pop, 2014; Höghielm, 2010; Aleandri \& Refrigeri, 2013).

Construction skills are parts of the concern of vocational education and necessary to be studied given the existing gap between the reality of traditional working culture of the construction workers on the one hand and the demands and competition of the modern construction industry on the other hand. In this respect, this paper explores to what extent they carry out the andragogic instruction. The identification includes recruitment pattern, network development, skill acquisition and transfer, responses to technology, and established attitudes and values.

\footnotetext{
Vol. 10, No. 2 | December 2018| ISSN 2229-8932 Journal of Technical Education and Training (JTET)| 72
} 


\section{MATERIALS AND METHODS}

\subsection{Research approach}

This study used qualitative (Agustinova, 2015; Denzin \& Lincoln, 2000; Creswell, 2014), ethnography and ethno-andragogic methods (Spradley, 1979; Denzin \& Lincoln, 2000; Murchison, 2009; Saldana, 2009; Strauss, 1987). The purpose is to describe, analyze and interpret construction workers' tradition of construction skill learning and training that establishes work culture inheritance pattern among generations

\subsection{Research participants}

The participants were construction workers of Sudalarang Village, Sukawening District, Garut, West Java, Indonesia. The research involved 35 informants who came from three generations of construction workers. We selected eight informants, who represent each generation for in-depth interviews. The selection of informants is in compliance with the requirements of ethnographic informants. The selection process went through a preliminary data collection and a focus discussion group to map their expertise. The informants were then categorized into the main informants, who's more than 30 years of experience and have inherited their knowledge to younger workers, and the supporting informants, who are still actively working in construction projects.

\subsection{Data collection}

The data were collected through participant observation, in-depth interview, and document analysis. The data collection was carried out in accordance with Spardley's (1979) procedures comprising: locating informants, interviewing informants while explaining to them the research objectives to build rapport and understanding between the researchers and the informants, and making an ethnographic record, in which detailed field notes were noted. The questions included descriptive questions, structural questions, and contrast questions.

\subsection{Data Analysis and theme interpretation}

Ethnographic research contains insightful analysis derived from specific ethnographic data (Murchison, 2010). The analysis went through coding, in which events, interview notes, insightful moments, and other field experiences were identified (Saldana, 2009); theme interpretation, which was supported by triangulations between concepts and theories, among informants, and other sources; and writing the ethnography, which was conducted inductively from data collection, data categorization, and interpretation abstraction (Strauss, 2003).

\section{RESULTS AND DISCUSSIONS}

\subsection{Construction workers of Sudalarang Village}

Sociologically, Sudalarang people have strong emotional attachment to their village so that they will remain villagers and collaboratively build their place of origin. Villagers working in the city can almost certainly bring in their income to develop their socio-economic life in the village. The workers are temporary residents in urban areas as they are involved in various construction works and then bring their 
income to support families in the village. The generation network of construction workers from Sudalarang village is depicted as in Figure 1.

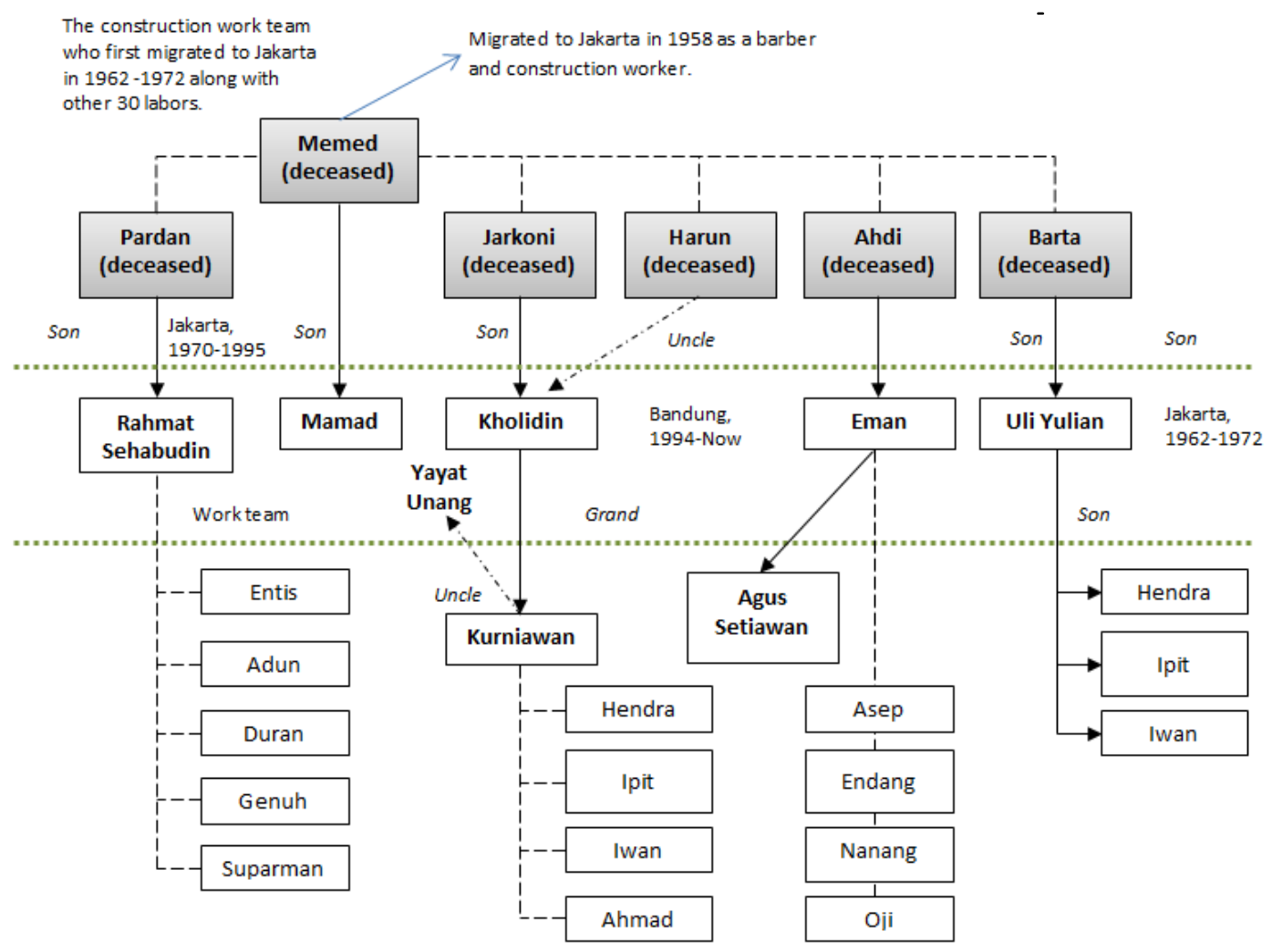

Figure 1: A 3-Generation network of construction workers from Sudalarang (Source: Research Documentation 2017)

Note:

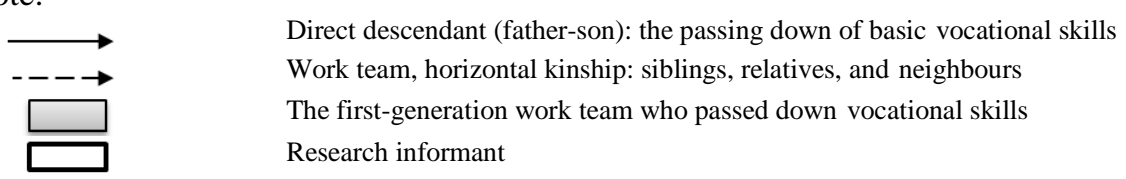

The construction worker group from Sudalarang was first involved in major projects in Jakarta after following Mr. Memed who entered Jakarta in 1958. Mr. Memed is the first worker who served as a leader to the construction workers from Sudalarang. The network of construction workers has long been established at least since 1962 where they were involved in the construction of Gelora Bung Karno Stadium. Those who followed Mr. Memed were Mr. Pardan, Mr. Jarkoni, Mr. Uli, Mr. Barta, Mr. Harun, and other 30 people who then stayed in Jakarta in the period of 1962-1972 (Figure 1). Their involvement in the construction of Gelora Bung Karno Stadium became a historic recount their descendants, who now also become construction workers, are proud of so as to show how strong their lineage is in the sector of construction industry. The distribution of Sudalarang construction workers are shown in Figure 2. 


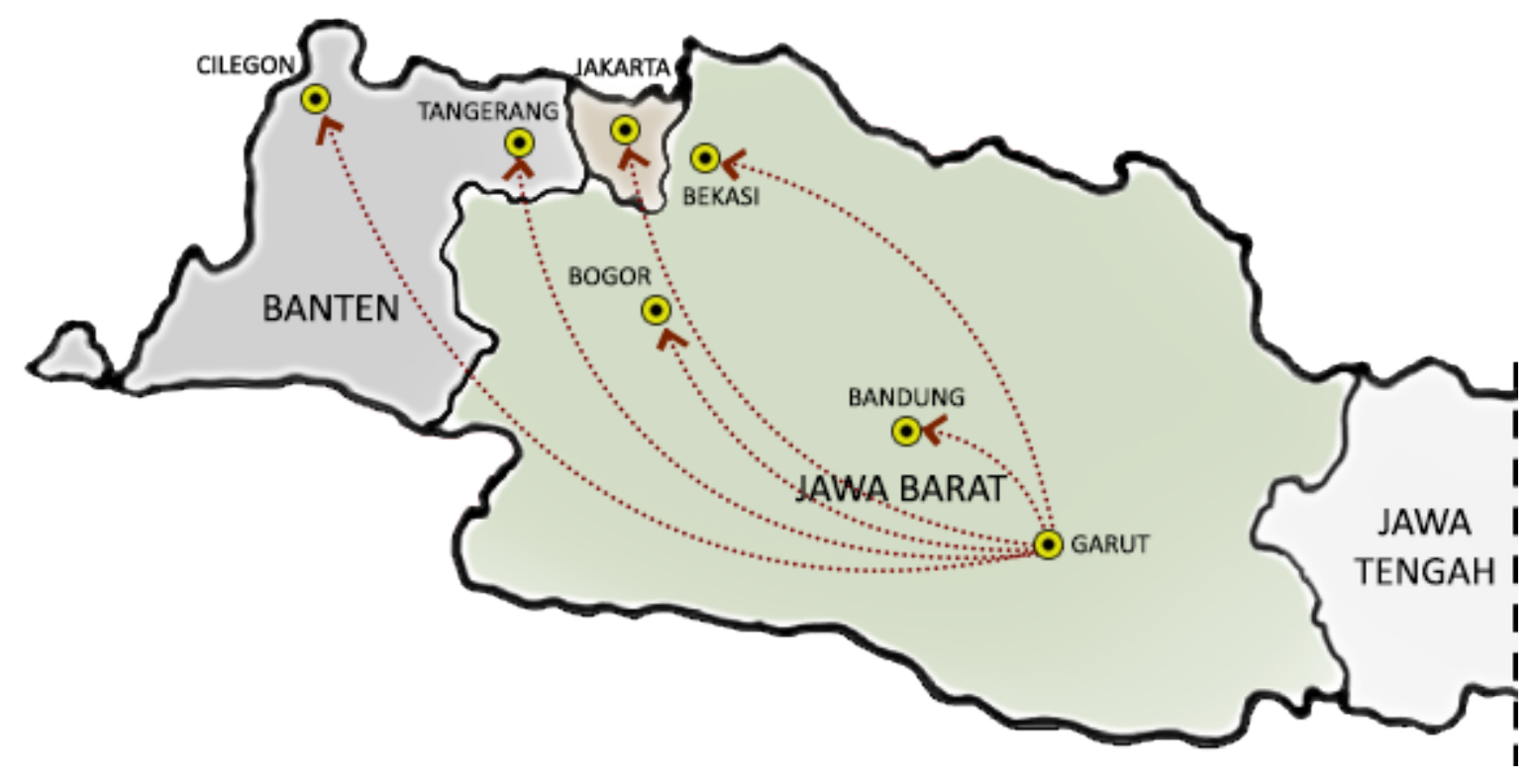

Figure 3: Distribution of Sudalarang construction workers (Source: Research Data, 2017)

The passing down of construction skills through generations are reflected in their relationship pattern and the training process occurring at their working fields. Their migration to urban areas is temporary as they moved from one place to another. In sociological study, labor migration has been an important issue in many countries because it not only has to do with their individuals per se, but also with geographical, economic, politic, and social change issues in both national and international scale (Vasile, 2014; Atramentova, Luchko, \& Filiptsova, 2017; Oğuz, 2011; Hoang, Yeoh, \& Wattie, 2012; Kancs, 2011). Regardless of the purpose, in general labor migration is part of a larger global trend that affects population density in the cities (Sira \& Dubravska, 2015). The backgrounds of most labor migration cases are essentially to earn a better income even though they are not well-educated, inexperienced, and lessskilled (Boboc, Vasilem, Ghiță \& Covrig, 2014).

The target cities of most labor migrations were Jakarta, Bandung, Tangerang, Bekasi, and Tangerang. The workers mostly worked in Jakarta (4 groups of workers) and Bandung (3 groups), while the remaining worked in Tangerang, Bekasi, Bogor, and Garut (Figure 2). One of the informants even had experienced of working in construction industry in Japan. The informant distribution illustrates the movement pattern of the temporary labors in urban areas by involving in many different construction project locations. They learn by doing on the job, and then will eventually go back to their hometown.

\subsection{Inheritance pattern of vocational skills}

\section{Recruitment Pattern}

Labor input management including recruitment process is crucial to the sustainability of a construction project. The lowest-level construction workforce called craftsmen plays a major role so that it is necessary to identify the various interests and factors that affect their performance (Kazaz \& Ac, 2015; Kazaz, Ulubeyli, Acikara, \& Er, 2016; Soekiman, Pribadi, Soemardi, \& Wirahadikusumah, 2011). However, this 
industry is a low skills sector labour market whose human resources range from different educational backgrounds, so performance in the field will be determined by how far the learning process in the workplace goes according to the demands of the need.

Despite the use modern technology, the need for human labour in the construction industry is still quite high and even employment in this sector continues to increase. Recruitment carried out in construction projects in Indonesia still uses the traditional system, not through the selection process, without any written application, induction, and pre-employment training.

As shown in Figure 1, the recruitment process is based on kinship and friendship. All informants being in-depth interviewed were direct descendants of the previous construction workers. Kinship and friendship are crucial to them for a variety of reasons. Mr. Eman who until now still constantly get construction project works in Bandung said, "it is necessary to establish a network with people I know very well because I know who they really are, their attitudes, and habits that influence their work performance.” In a wider context, this pattern is also related to such factors as trust, convenience in communication, and the economic sustainability of family, relatives and local community. Mr. Kurniawan, an informant of the youngest generation who always manage to get construction projects in Jakarta, Bekasi, and Tangerang, said, "I always urge the unemployed youth in my village to come and join my work team. [It is] better than being unemployed. I am selective, though. They must be honest, willing to learn, and ready to work hard." Good behaviour, honesty, willingness to learn and to work hard, and being able to work in a team are the key prerequisites for them to be recruited by the informants. Soft skills become the most considered in the recruitment process. There has never been any skill testing due to their principle saying, "Skills can be developed while working."

\section{Learning by Doing}

As construction workers become teamwork on a construction project, their educational background is not important. To them, skills can be developed while working. Mr. Kholidin said, "In construction, if you really want to learn by doing, there is nothing to it. Skills can automatically be developed while working." On the other hand, the informants also admitted that the level of formal educational they received influence their learning pace and skill development. Experienced for more than 30 years, he has acquired and transferred skills to their subordinates who come from various educational backgrounds. the skill acquisition stage of each worker is reflected in their gradual increasing position, from assistant and to the chief craftsman. Empirically, skills will be more qualified if obtained through the process of learning on the job (Gavrel, Lebon, \& Rebière, 2016). The survival of every worker in the construction industry is determined by his awareness to always learn and readiness to change and face competition challenges.

This construction skill transfer is a process of cultural inheritance in a community, regardless of whether this practice is still relevant with the demands of modern industry. In fact, they could adapt to the advance of construction technology as proven by their involvement in various construction projects, from average houses to buildings with high complexity. They acquire knowledge and skills through the process of learning on the job and learning by doing. The skills the informants acquired through the cultural inheritance continue to develop along the way. As a case in point, below is the illustration of how a carpenter named Rahmat Sihabudin acquired his skills (Figure 3). 


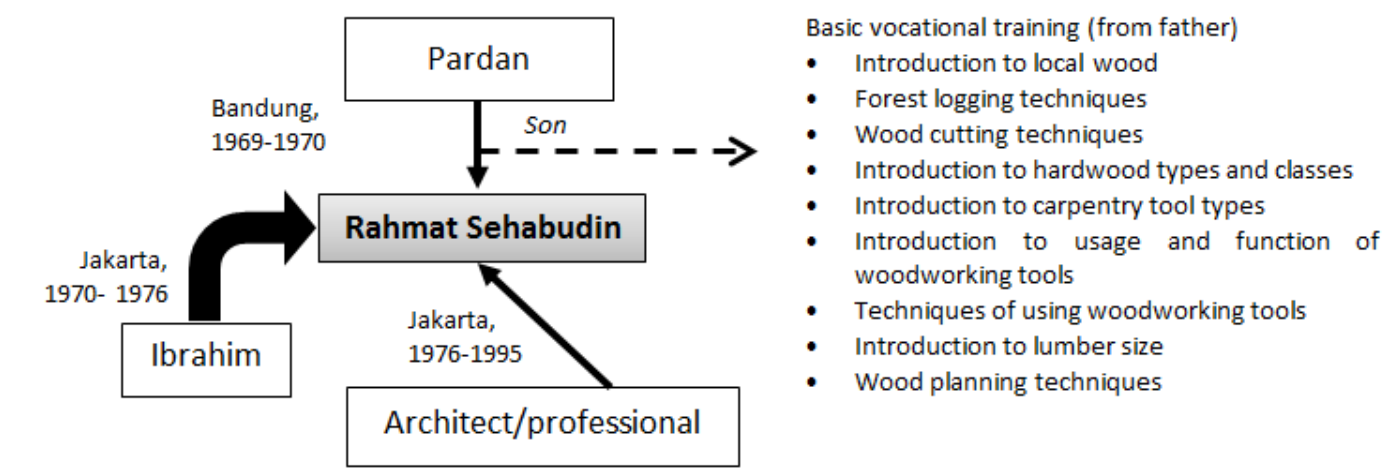

Advanced vocational training (first employer):

- Introduction to imported wood types

- Wood cutting techniques for door/window frames and trusses

- Processing techniques of joints, sponning, profiles

- Introduction to wood cutting terms and their functions

- Connecting techniques

- Door/window frame installation techniques

- Span and joint calculation

- Truss slope calculation

Skill development (professional):

- Work attitude and discipline

- Introduction to wood machining tools

- Introduction to technical drawing

- Technical drawing reading skill and its application to woodworking

- Introduction to force and load calculation (mechanics of material)

- Construction strength calculation techniques

- High complexity works (multi-storey buildings, variety of wooden construction designs).

- Wide truss

Figure 3: Example of inheritance pattern of vocational skills (Source: Research Data 2017)

\section{Skills Development}

Humans are ethical creatures (Kesuma, 2016), one of whose responsibilities is to transform. As transforming beings, humans are not merely passive actors in the development of civilization. Human's continuous experience and experimentation bring about a tradition of instilling values, attitudes, knowledge and skills that are different from one country to another. Transformation in a more specific context is also related to the concept of human potentials. In this respect, Marx refers to humans as species-beings, meaning that it is the unique human potentials that make humans different from other species (Ritzer, 2012:79). It is essential for humans to work and to be a worker. Human basic potentials will develop if they can adapt to changes in their work fields.

Mr. Kholidin reached the peak of his career as chief craftsman in various projects in Jakarta, overseeing 40 workers coming from various places. With only working experience as a farmworker, he began to come to Jakarta in 1970s following his uncle and became an assistant to skilled construction workers. His participation in various construction projects enables him to interact with and at the same time learn from his supervisors from professional circles. He began to change his fate in Jakarta after he received training in project cost estimate preparation and concrete reinforcement from the Ministry of Public Works. Like Mr. Kholidin, Rahmat Sihabudin and Eman are also actively involved in various residential projects in Bandung. They independently develop their basic skills inherited from their parents and by learning from architects or civil engineers at work.

Kurniawan, an electrical engineering vocational high school graduate, was recruited by his uncle to work in construction projects. In his being an assistant for a year, he is trained the basic skills of bricklaying and wooden truss construction. The trend shift in terms of material use and the advance 
technology require him to learn new things. Equipped with IT literacy he acquired from his school, he managed to develop his vocational skills by learning from the Internet. His current specialization includes light steel framing and concrete reinforcement. He said, "I am assigned by my supervisor to learn light steel framing, welding, and reinforcement. I always learn by directly observing how the more skilful people do things and then look it up on the Internet. His current success in administering various construction projects convinces him that work skills can be learned by doing in the field.

Figure 4 shows the pattern of skills improvement and career development as extracted from interviews with the informants. During the early phase, which took four months to a year, the informants were trained as assistants and guided workers. The workers passed through the second phase, in which they developed their skill, experienced the dynamics of career development, and achieved the peak of their career. This phase might take 2-40 years until they had to cease working due to age and physical constraints. Those who had transferred their knowledge to the next generation would stay in the village and would no longer work in cities.

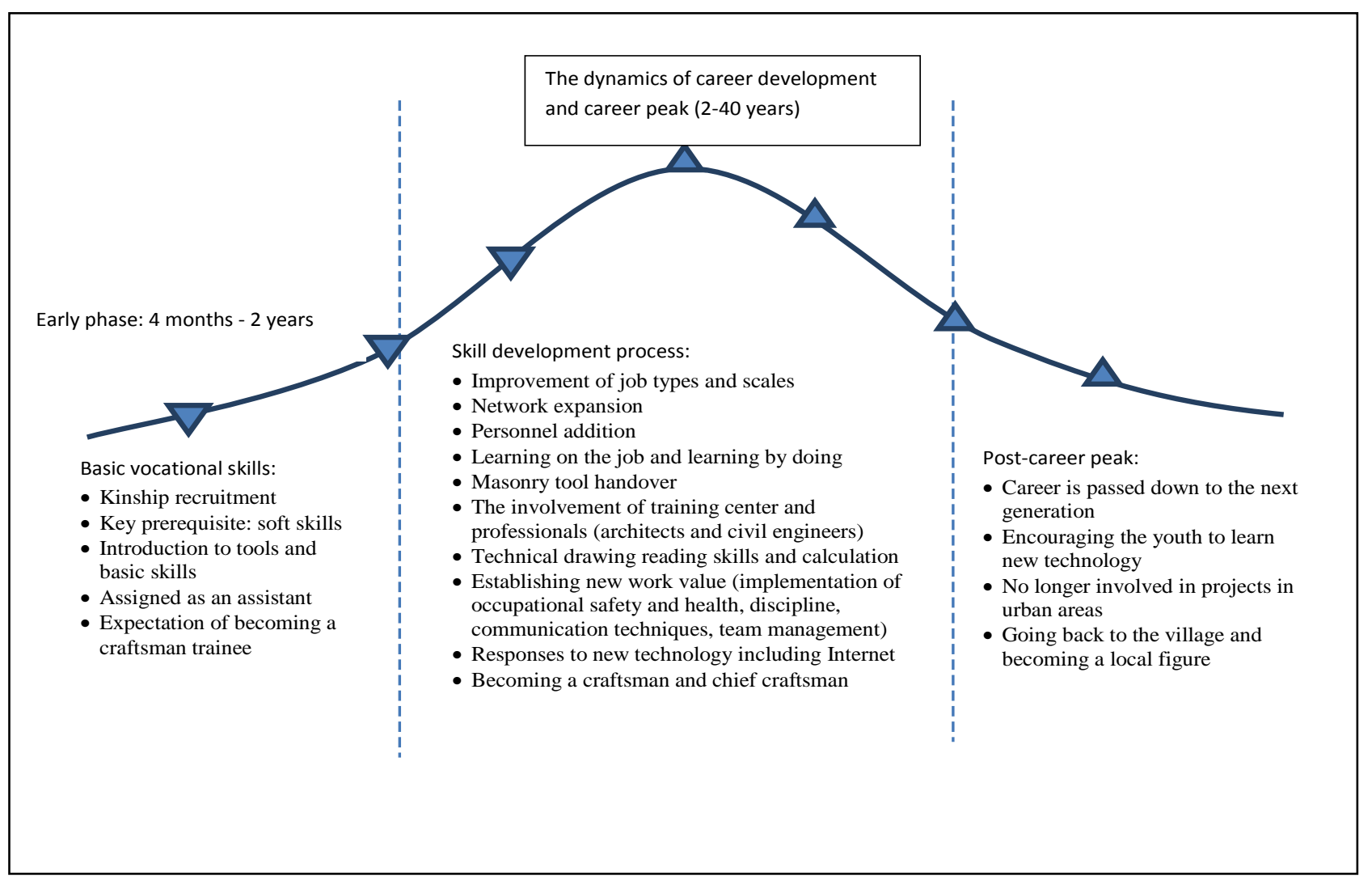

Figure 4:Vocational skills development pattern (Source: Research Data, 2017)

Education in a wider perspective is not limited by place, time, and how learning can takes place (Coombs \& Ahmed, 2005). As a matter of fact, education is not limited to academic skills and textbooks or school instructional materials, but includes the ability to work to survive, daily work, the formation of attitudes, values, the mastery of certain skills and knowledge acquisition. Parents (father or uncle) become the first trainer in every generation, transferring basic vocational skills by involving their children (or 
nephews) directly into works gradually. Skills can develop along the way when the network is expanded and new knowledge is acquired form new supervisors, professionals, training centres, and skill development through Internet. The informants' skills become an important description of andragogy to take into account for the development of vocational skill teaching and learning process (Schied, 2014).

Andragogic principles allow individuals to develop their skills in science, technology, social, culture and economics, as well as preparing themselves to develop different skills in different areas of interest through their knowledge and abilities (Kocak \& Baskan, 2012). The instruction can take place anywhere, anytime, and with anyone. Therefore, the learning can begin from early age phase to adult age phase in both formal and informal education (Laal, Laal, \& Aliramaei, 2104). The vocational skill inheritance pattern illustrates informal education different from formal educational system especially in terms of teacher-student relationships and the teaching and learning process. Practical needs in the field become the basis of teaching process. The informants are trained and re-transfer his acquired skills and directly put them into work.

\section{CONCLUSION}

Ideally, vocational skills are trained in formal education whose curriculum is oriented to meet the demands of job markets. However, what happens in Indonesia's construction industry is that the construction workers acquired their skills through cultural inheritance from their previous generations. The training begins with kinship and friendship recruitment. Basic skills are passed down through generations by learning on the job. Educational background does not matter to them as long as the can learn by doing and work hard to improve their skills. Their career and vocational skills development can take place in many different work places. The training they receive from professionals and training centres become their way of transforming themselves. This pattern is still maintained up to now. None of those entering the job market in the construction industry begins with their formal education in the vocational schools specializing in the field. For them, the most important thing is to involve their relatives and local community members in their teamwork. Soft skills that are related to morality, honesty, and willingness to hard work and the ability to work in a team are the most considered. This study contributes to providing basic information for further research on the issue of marginalized construction workers'

vocational skill. The findings are expected to provide comprehension of construction workers' skill improvement, based upon which policies on their trainings should be developed.

\section{References}

Agustinova, Danu Eko. (2015). Memahami Metode Penelitian Kualitatif. Teori dan Praktik. Penerbit Calpulis, Yogyakarta.

Aleandri, G., \& Refrigeri, L. (2013). Lifelong learning, training and education in globalized economic systems: Analysis and perspectives. Procedia - Social and Behavioral Sciences, 93, 1242-1248. http://doi.org/10.1016/j.sbspro.2013.10.022

Amir, F., Martini, \& Luthfiah. (2013). Peningkatan keahlian tukang dan buruh bangunan dalam membangun rumah sederhana aman gempa di Kota Palu. Mektek.

Atramentova, L., Luchko, E., \& Filiptsova, O. (2017). Impact of migration on the expression of aggression and empathy in urban populations. Egyptian Journal of Medical Human Genetics, 4-7. http://doi.org/10.1016/j.ejmhg.2017.06.004

Badaruddin, Samuel, JP. (2015). Potensi modal sosial buruh bangunan (studi deskriptif terhadap buruh bangunan di Lingkungan 12 Desa Bandar Khalifah Kecamatan Percut Sei Tuan Kabupaten Deli Serdang. Jurnal Perspektif Sosiologi, 3(1), Oktober 2015. 
Boboc, C., Vasile, V., Ghiță, S., \& Covrig, M. (2014). Romanian labour migration: Employees perspective. Procedia Economics and Finance, 10(14), 244-248. http://doi.org/10.1016/S2212-5671(14)00299-8

Coombs, PH. Ahmed, Manzoor. (2001). New Path to Learning. New York: International Council for Educational Development.

Creswell, J. W. (2014). Research Design: Qualitative, Quantitative and Mixed Methods Approaches. SAGE Publications, Inc.

Denzin, N. K., \& Lincoln, Y. S. (2000). Handbook of Qualitative Research. New Delhi: SAGE Publications.

Eaves, S., Gyi, D. E., \& Gibb, a. G. F. (2016). Building healthy construction workers: Their views on health, wellbeing and better workplace design. Applied Ergonomics, 54, 10-18. http://doi.org/10.1016/j.apergo.2015.11.004

Denzin, N. K., \& Lincoln, Y. S. (2000). Handbook of Qualitative Research. New Delhi: SAGE Publications.

Fraenkel, J. R., \& Wallen, N. E. (2007). How to Design and Evaluate Research in Education. New York: Mic Graw Hill.

Gavrel, F., Lebon, I., \& Rebière, T. (2016). Formal education versus learning-by-doing: On the labor market efficiency of educational choices. Economic Modelling, 54, 545-562. http://doi.org/10.1016/j.econmod.2016.01.006.

Haryadi, Bada (2010). Kompetensi tenaga kerja konstruksi dalam menghadapi globalisasi. Jurnal Inersia, Vol.VI No 1 Mei 2010.

Hoang, L. A., Yeoh, B. S. a, \& Wattie, A. M. (2012). Transnational labour migration and the politics of care in the Southeast Asian family. Geoforum, 43(4), 733-740. http://doi.org/10.1016/j.geoforum.2011.12.006.

Höghielm, R. (2010). Adult basic education: A challenge for vocational based learning. International Encyclopedia of Education, 102-106. http://doi.org/10.1016/B978-0-08-044894-7.00018-X

Kancs, d'Artis. (2011). The economic geography of labour migration: Competition, competitiveness and development. Applied Geography, 31(1), 191-200. http://doi.org/10.1016/j.apgeog.2010.04.003

Kazaz, A., \& Ac, T. (2015). Comparison of Labor Productivity Perspectives of Project Managers and Craft Workers in Turkish Construction Industry. Procedia - Procedia Computer Science, 64, 491-496. http://doi.org/10.1016/j.procs.2015.08.548.

Kazaz, A., Ulubeyli, S., Acikara, T., \& Er, B. (2016). Factors affecting labor productivity: perspectives of craft workers. Procedia Engineering, 164(June), 28-34. http://doi.org/10.1016/j.proeng.2016.11.588

Kesuma, D., \& Ibrahim, T. (2016). Struktur Fundamental Pedagogik (Membedah Pemikiran Paulo Fraire). Bandung: PT Refika Aditama.

Kocak, S., \& Baskan, G. A. (2012). Village Institutes and Life-long Learning. Procedia - Social and Behavioral Sciences, 46, 5937-5940. http://doi.org/10.1016/j.sbspro.2012.08.009

Laal, M., Laal, A., \& Aliramaei, A. (2014). Continuing education; lifelong learning. Procedia - Social and Behavioral Sciences, 116, 4052-4056. http://doi.org/10.1016/j.sbspro.2014.01.889.

Murchison, Julian. (2010). Ethnography Essentials. Designing, Conducting, and Presenting Your Research. Published by Jossey-Bass, San Fansisco.

Oğuz, G. (2011). The impact of Turkish labour migration on the human resources in the European Union. Procedia Social and Behavioral Sciences, 24, 696-715. http://doi.org/10.1016/j.sbspro.2011.09.001.

Ritzer, Geoge. (2012). Eight Edition. Sosiology Theory. Published by McGraw Hill. New York.

Rothenberg, A. D., Gaduh, A., Burger, N. E., Chazali, C., Tjandraningsih, I., Radikun, R., ... Weilant, S. (2016). Rethinking Indonesia's Informal Sector. World Development, 80, 96-113. http://doi.org/10.1016/j.worlddev.2015.11.005.

Sălcudean, I. N., Vereş, V. A., \& Pop, C. M. (2014). The social and cultural dimension of lifelong learning in the European Union. Study case: Babes-Bolyai University. Procedia - Social and Behavioral Sciences, 142, 162168. http://doi.org/10.1016/j.sbspro.2014.07.634.

Saldana, Johnny (2009). The Coding Manual for Qualitative Researchers. SAGE Publication Ltd.

Schied, F. M. (2014). Critical perspectives on the skills debate:Implications for adult education. Procedia - Social and Behavioral Sciences, 142, 553-556. http://doi.org/10.1016/j.sbspro.2014.07.665.

Sira, E., \& Dubravska, M. (2015). Current trends of migration in the Slovak Republic (Case Study). Procedia Economics and Finance, 23(October 2014), 461-466. http://doi.org/10.1016/S2212-5671(15)00558-4.

Spradley, James P. (1979). The Etnographic Interview.

Vol. 10, No. 2 | December 2018| ISSN 2229-8932 Journal of Technical Education and Training (JTET)| 80 
Soekiman, a., Pribadi, K. S., Soemardi, B. W., \& Wirahadikusumah, R. D. (2011). Factors relating to labor productivity affecting the project schedule performance in Indonesia. Procedia Engineering, 14, 865-873. http://doi.org/10.1016/j.proeng.2011.07.110

Strauss, Anselm.L (2003). Qualitative Analysis For Social Scientists. Cambridge University Press. University of California, San Fransisco and Tremont Research Institute, San Fransisco.

Vasile, V. (2014). Labour mobility impact on sending countries. Romanian EU workers case study. Procedia Economics and Finance, 8(14), 737-746. http://doi.org/10.1016/S2212-5671(14)00152-X

Widaningsih, L., Megianti, T., Susanti, I. (2016). Needs Identification in Strengthening the Skills of Construction Workers with the National Working Competency Standards. Taylor \& Francis Group, London, UK 